\title{
Improvement of the Performance of Purple Carrot Sensitized Solar Cells by Acidic Treatment of FTO Glass Substrate and $\mathrm{TiO}_{2}$ Film
}

\author{
I.M. RAdWAN ${ }^{a}$, S.A. TAYA ${ }^{a, b, *}$, T.M. El-AGEZ ${ }^{a, b}$, M.S. ABDEL-LATiF ${ }^{b, c}$ AND H.S. Ghamri ${ }^{a, b}$ \\ ${ }^{a}$ Physics Department, Islamic University of Gaza, Gaza, Palestine \\ ${ }^{b}$ Renewable Energy Center, Islamic University of Gaza, Gaza, Palestine \\ ${ }^{c}$ Chemistry Department, Islamic University of Gaza, Gaza, Palestine
}

(Received October 10, 2015; in final form June 10, 2016)

\begin{abstract}
In this paper, dye sensitized solar cells were prepared using titanium dioxide $\left(\mathrm{TiO}_{2}\right)$ and natural dye extracted from purple carrot. The performance of dye sensitized solar cells was significantly improved through the pre- and post-treatments of the fluorinated tin oxide (FTO) glass substrate and the $\mathrm{TiO}_{2}$ film using hydrochloric ( $\mathrm{HCl}$ ), phosphoric $\left(\mathrm{H}_{3} \mathrm{PO}_{4}\right)$, and nitric $\left(\mathrm{HNO}_{3}\right)$ acids. The results showed that the pre-treatment of the $\mathrm{FTO}$ with $\mathrm{H}_{3} \mathrm{PO}_{4}$ and the post-treatment of $\mathrm{TiO}_{2}$ with $\mathrm{HNO}_{3}$ resulted in improved efficiencies of $130 \%$ and $250 \%$, respectively.
\end{abstract}

DOI: $10.12693 /$ APhysPolA.130.795

PACS/topics: 88.40.-j , 88.40.H-

\section{Introduction}

The supply of clean sustainable energy is considered as one of the most important scientific and technical challenges facing humanity in the 21st century. Sun has always been the most powerful energy source on earth since it satisfies all requirements of the energy source. It is clean, environmentally friendly and freely available. Sunlight can be transformed into electricity using solar cells. The solar cell that currently has the largest share in the market is based on crystalline silicon which was first reported by Chapin in 1954 [1]. Even if the efficiency since then has increased and the production cost decreased, it is still too expensive to be able to compete with the conventional energy sources. This has led to a great research interest in finding new ways of utilizing the solar energy with cheaper and more efficient techniques. Dye sensitized solar cells (DSSCs) are considered as one of the most promising solar cells for future clean energy supply [2-10]. It consists of a working electrode with a porous layer of a nanocrystalline wide bandgap semiconductor, such as $\mathrm{TiO}_{2}$, sensitized with a dye which plays a critical role in light absorption, a redox electrolyte (e.g. $\mathrm{I}_{3}^{-} / \mathrm{I}^{-}$) and a counter electrode, for instance, platinized conductive glass. Recently, research has been focused on the easily available dyes extracted from natural sources as photosensitizers because of high light-harvesting efficiency, low cost, easy preparation and environment friendliness. Calogero et al. studied a group of natural pigments containing anthocyanins. These extracts gave a short circuit current up to $8.8 \mathrm{~mA} / \mathrm{cm}^{2}$ and an open circuit voltage of $419 \mathrm{mV}$. The best solar conversion efficiency of $2.06 \%$ with Sicilian prickly pear extract was obtained [11]. A set of natural dyes were extracted from flower petals, leaves and bark and tested as photosensitizers [12]. The extracts of rosella flowers and black rice were used as sensitizers and an efficiency of $0.37 \%$ and $0.327 \%$, respectively, was obtained [13]. For the extract of black rice, a blue-shift of its absorption wavelength was observed related to better interaction between the carbonyl and hydroxyl groups of anthocyanin molecule on black rice extract and the surface of $\mathrm{TiO}_{2}$ porous film $[13,14]$.

Many researches tried improving the performance of different dyes by acidic treatments. For example, treating $\mathrm{TiO}_{2}$ thin films by $\mathrm{HCl}$ before the adhesion of the so-called black dye led to a major contribution to the photocurrent resulting in an improvement of the overall efficiency by $10.5 \%$ [15]. Moreover, according to Watson et al. the acidic treatment led to self-assembly of a scattering "skin" on the surface of $\mathrm{TiO}_{2}$ film leading to an increase of the path length of light incident on the $\mathrm{TiO}_{2}$ film which is similar to the function of a scattering layer but without any additional depositions [16]. This effect was clearly obvious in improving electrical conductivity leading to reduced recombination. Treating the DSSC sensitized with Glycyrrhiza glabra with $\mathrm{HCl}$ led to an efficiency enhancement of about $300 \%$ [17].

The objectives of this work were to prepare DSSCs using $\mathrm{TiO}_{2}$ as a semiconducting layer and natural dye extracted from purple carrot and to study the influence of pre-treatment and post-treatments of the fluorinated tin oxide (FTO) glass substrate and the $\mathrm{TiO}_{2}$ film using different acids. The photovoltaic properties of the fabricated cells were investigated and the electrochemical impedance spectroscopy was carried out for the fabricated DSSCs. 


\section{Experiment}

The plant root of purple carrot was washed with distilled water. The root was then dried for $24 \mathrm{~h}$. One gram of the root was immersed in $10 \mathrm{ml}$ of ethanol at room temperature and kept in the dark for one day. After filtration of the solutions, natural extract was obtained.

FTO glass substrates (resistance $12-14 \Omega / \mathrm{cm}^{2}$, transmittance $82-84 \%$; purchased from Xinyan Technology Ltd, Hong Kong) were cleaned in detergent solution, rinsed with de-ionized water and acetone and then dried in ambient conditions. The $\mathrm{TiO}_{2}(10-25 \mathrm{~nm}$, US Research Nanomaterial, Inc., USA) paste was prepared by adding $2 \mathrm{~g}$ of $\mathrm{TiO}_{2}$ nanopowder to $4 \mathrm{ml}$ distilled water. Then $10 \mu \mathrm{l}$ of acetylacetone were added to prevent the reaggregation of $\mathrm{TiO}_{2}$ particles. Finally $50 \mu \mathrm{l}$ of Triton X-100 were slowly added with continuous mixing for $30 \mathrm{~min}$ [5]. The $\mathrm{TiO}_{2}$ paste was spread uniformly over the FTO substrate using doctor-blade technique by adhesive tape as spacer on the two sides of the FTO sheet to confine the area and thickness of $\mathrm{TiO}_{2}$ film in order to obtain a $\mathrm{TiO}_{2}$ layer of thickness of about $20 \mu \mathrm{m}$. After drying, the $\mathrm{TiO}_{2}$ film was sintered at $450{ }^{\circ} \mathrm{C}$ for about $30 \mathrm{~min}$, then cooled down to $100^{\circ} \mathrm{C}$. The samples were immersed in the natural extract of the purple carrot for $24 \mathrm{~h}$. Finally, the two electrodes were assembled and the electrolyte redox $\left(\mathrm{I}^{-} / \mathrm{I}_{3}^{-}\right)$was spread within the vicinity between them using a micropipette. The redox electrolyte solution was composed of $2 \mathrm{ml}$ acetonitrile (ACN), $8 \mathrm{ml}$ propylene carbonate ( $p$-carbonate), $0.668 \mathrm{mg}$ potassium iodide $(\mathrm{KI})$, and $0.0634 \mathrm{mg}$ iodine $\left(\mathrm{I}_{2}\right)$. The redox electrolyte solution was sandwiched between the two electrodes. The photovoltaic properties of the untreated cells were studied.

To investigate the effect of the pre-treatment of FTO glass substrates using hydrochloric $(\mathrm{HCl})$, phosphoric $\left(\mathrm{H}_{3} \mathrm{PO}_{4}\right)$, or nitric $\left(\mathrm{HNO}_{3}\right)$ acids, FTO glass substrates were cleaned by acetone and ethanol successively for $20 \mathrm{~min}$ and immersed in $0.1 \mathrm{M}$ of one of these acids at room temperature for $5 \mathrm{~min}$ then washed with ethanol. The $\mathrm{TiO}_{2}$ paste was then spread uniformly on the treated FTO substrates. The cell was assembled as mentioned before.

Hydrochloric acid $(\mathrm{HCl})$, phosphoric acid $\left(\mathrm{H}_{3} \mathrm{PO}_{4}\right)$, or nitric acid $\left(\mathrm{HNO}_{3}\right)$ were also used to investigate the effect of surface post-treatment of $\mathrm{TiO}_{2}$ film on the efficiency of the fabricated DSSCs. Nanoporous $\mathrm{TiO}_{2}$ working electrodes were prepared on FTO substrates by doctor blade method. The electrodes were post-annealed at $450^{\circ} \mathrm{C}$ for $30 \mathrm{~min}$ and cooled down to $100^{\circ} \mathrm{C}$ in ambient air. Then, the $\mathrm{TiO}_{2}$ electrodes were soaked in $0.1 \mathrm{M}$ of $\mathrm{HCl}$, $\mathrm{H}_{3} \mathrm{PO}_{4}$ or $\mathrm{HNO}_{3}$ at room temperature for $5 \mathrm{~min}$ followed by washing with ethanol. After the treatments, the $\mathrm{TiO}_{2}$ electrodes were soaked in an ethanol solution of purple carrot extract at room temperature for $24 \mathrm{~h}$ and the cell was assembled.

Electrochemical impedance spectroscopy was conducted for the untreated DSSC using AUT 85276
Potentiostat-Galvanostat with frequency response analyzer FRA 32 Module device.

\section{Results and discussion}

\subsection{Absorption spectrum of purple carrot dye solution}

The UV-Vis absorption spectra of purple carrot dye solution and dye adsorbed onto $\mathrm{TiO}_{2}$ surface were carried out in the range 390-700 $\mathrm{nm}$ using GENESYS 10S UVVis spectrophotometer. Figure 1 shows the absorption spectra of anthocyanin solution extracted from purple carrot and that of the $\mathrm{TiO}_{2}$ electrode after being soaked in anthocyanin solution. As shown from the figure, a small peak at a wavelength of $427 \mathrm{~nm}$ and a large peak at $552 \mathrm{~nm}$ appear because of existing of an anthocyanin pigment. The photocurrents observed in DSSCs sensitized by purple carrot extracts are ascribed to anthocyanin. Anthocyanins are natural compounds that give color to fruits, flowers, leaves and roots of plants [6]. The carbonyl and hydroxyl groups presented in anthocyanin based dyes are responsible for the binding between anthocyanin molecule and $\mathrm{TiO}_{2}$ particles.

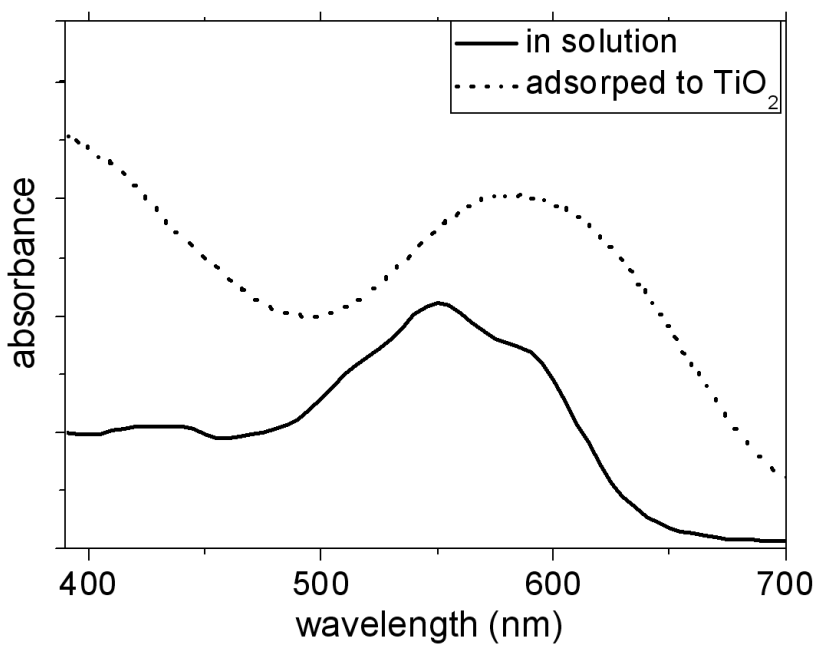

Fig. 1. Absorption spectra of purple carrot extract in ethanol solution and that adsorbed onto $\mathrm{TiO}_{2}$ film.

Anthocyanins are responsible for the unlimited colors from orange then red to purple and blue of several parts of plants. Chemically they belong to flavonoid compounds, which are widely distributed plant polyphenols. The anthocyanidins basic structure is a C6-C3-C6 carbon skeleton. The most commonly known anthocyanidins in nature are six: cyanidin, pelargonidin, peonidin, delphinidin, petunidin, and malvidin. Three of them have purple color according to their hydroxylation and methoxylation patterns.

\subsection{Acidic pre-treatment of FTO substrates}

The $J-V$ characteristics of the DSSCs with the pretreatment of FTO glass substrates with the three acids under an illumination of $100 \mathrm{~mW} / \mathrm{cm}^{2}$ are shown in 
Fig. 2. Moreover, the figure also shows the results of the untreated cell. Table I shows the photovoltaic parameters of the untreated and pre-treated DSSCs with hydrochloric $(\mathrm{HCl})$, phosphoric $\left(\mathrm{H}_{3} \mathrm{PO}_{4}\right)$, or nitric acids $\left(\mathrm{HNO}_{3}\right) . J_{\mathrm{sc}}$ and $V_{\mathrm{oc}}$ represent the short circuit current density and open circuit voltage whereas $J_{\mathrm{m}}$ and $V_{\mathrm{m}}$ are the current and voltage of the maximum power point. $\mathrm{FF}$ and $\eta$ are the fill factor and conversion efficiency. It is clear that the DSSCs exhibited improved efficiencies after the pre-treatment of the FTO with any of the three acids. The reason for that may be attributed to the decrease of the sheet resistance of the FTO glass substrate by the acid treatment then the nanoparticles enhance the surface area and suppress the charge recombination [5]. The pre-treatment of the FTO also increases the contact points between the $\mathrm{TiO}_{2}$ film and the FTO and improves the electronic interconnection, so that the photoelectrons can be collected efficiently and the probability of electron recombination is reduced. The pre-treatment of the FTO with $\mathrm{H}_{3} \mathrm{PO}_{4}$ showed an improved efficiency of $130 \%$. It is worth mentioning that three cells of each kind were prepared and the average value was considered.

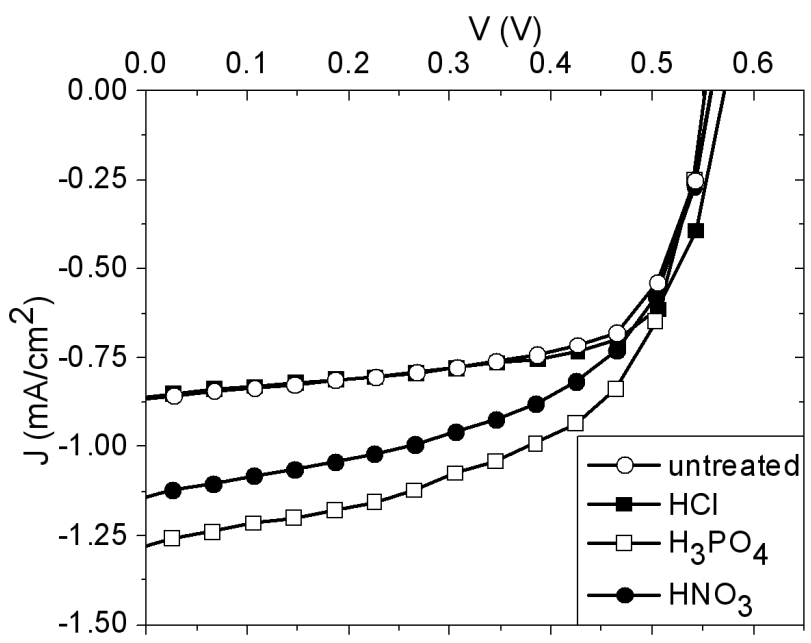

Fig. 2. Current density $(J)$ versus voltage $(V)$ characteristic curves of DSSCs with the pre-treatment of FTO glass substrates with $\mathrm{HCl}, \mathrm{H}_{3} \mathrm{PO}_{4}$, and $\mathrm{HNO}_{3}$ acids.

\section{TABLE I}

Photovoltaic parameters of the DSSCs with the pretreatment of FTO glass substrates by $\mathrm{HCl}, \mathrm{H}_{3} \mathrm{PO}_{4}$, and $\mathrm{HNO}_{3}$ acids.

\begin{tabular}{c|c|c|c|c|c|c}
\hline \hline $\begin{array}{c}\text { FTO } \\
\text { Pre-treatment }\end{array}$ & $\begin{array}{c}J_{\mathrm{sc}} \\
{\left[\mathrm{mA} / \mathrm{cm}^{2}\right]}\end{array}$ & $\begin{array}{c}V_{\mathrm{oc}} \\
{[\mathrm{V}]}\end{array}$ & $\begin{array}{c}J_{\mathrm{m}} \\
{\left[\mathrm{mA} / \mathrm{cm}^{2}\right]}\end{array}$ & $\begin{array}{c}V_{\mathrm{m}} \\
{[\mathrm{V}]}\end{array}$ & $F F$ & $\begin{array}{c}\eta \\
{[\%]}\end{array}$ \\
\hline $\begin{array}{c}\text { untreated } \\
\mathrm{HCl}\end{array}$ & 0.87 & 0.56 & 0.68 & 0.47 & 0.65 & 0.31 \\
$(0.1 \mathrm{M}, 5 \mathrm{~min})$ & 0.87 & 0.57 & 0.70 & 0.47 & 0.65 & 0.32 \\
$\begin{array}{c}\mathrm{H}_{3} \mathrm{PO}_{4} \\
(0.1 \mathrm{M}, 5 \min )\end{array}$ & 1.28 & 0.55 & 0.94 & 0.43 & 0.57 & 0.40 \\
$\begin{array}{c}\mathrm{HNO}_{3} \\
(0.1 \mathrm{M}, 5 \text { min })\end{array}$ & 1.14 & 0.56 & 0.82 & 0.43 & 0.55 & 0.35
\end{tabular}

\subsection{Acidic post-treatment of $\mathrm{TiO}_{2}$ film}

DSSCs with untreated electrodes with acids, together with post-treated $\mathrm{TiO}_{2}$ electrodes are tested under $100 \mathrm{~mW} / \mathrm{cm}^{2}$ intensity. Their characteristic $J-V$ curves are plotted in Fig. 3 whereas their photovoltaic parameters are summarized in Table II. Acid treated cells exhibited enhanced $J_{\mathrm{sc}}$ in comparison with untreated cells. DSSCs treated with $\mathrm{HCl}, \mathrm{H}_{3} \mathrm{PO}_{4}$ and $\mathrm{HNO}_{3}$ showed $J_{\text {sc }}$ values of $1.15,1.22$, and $2.90 \mathrm{~mA} / \mathrm{cm}^{2}$ and reduced $V_{\mathrm{Oc}}$ values of $0.52,0.51$, and $0.49 \mathrm{~V}$, respectively. $\mathrm{HNO}_{3}$ treated cells showed the highest efficiency of $\eta=0.81 \%$ and other parameters of $J_{\mathrm{sc}}=2.90 \mathrm{~mA} / \mathrm{cm}^{2}, V_{\mathrm{oc}}=$ $0.49 \mathrm{~V}$ and $F F=0.57$ whereas the untreated cell gave an efficiency of $\eta=0.31 \%$, and other parameters of $J_{\mathrm{sc}}=0.87 \mathrm{~mA} / \mathrm{cm}^{2}, V_{\mathrm{oc}}=0.56 \mathrm{~V}$ and $F F=0.65$. The $\mathrm{HNO}_{3}$ treated cells showed an efficiency enhancement of about $250 \%$.

These results may be attributed to the acid contributed regular arrangement of the photoelectrode via the dispersion of $\mathrm{TiO}_{2}$ particles. This dispersion is one of the factors that make much chemisorption site for the organic dyes. In addition, another reason behind this behavior may be attributed to the enhancement of the neck points between the nanoparticles which provides an improvement of $\mathrm{TiO}_{2}$ electrical conductivity leading to an increased dye loading and minimizing the recombination rate between the $\mathrm{TiO}_{2}$ film and the mediator [10]. The positively charged $\mathrm{TiO}_{2}$ surface formed by nitric acid treatment induces high electrostatic attraction between the reaction sites and anionic dyes, resulting in a much faster adsorption reaction [11]. Another explanation for positive impact of $\mathrm{TiO}_{2}$ protonation might be lowering the conduction band energy, which better fits to the position of the dye excited state and facilitates electron injection (lowering $V_{\mathrm{oc}}$ of the cells with higher current seams to confirm this, see Table II). This effect is similar to the effect of increase of the amount of cations $\left(\mathrm{Li}^{+}\right.$or $\left.\mathrm{K}^{+}\right)$ in the electrolyte.

These improvements are comparable with those obtained in Refs. [19] and [21]. In the present work, treating the $\mathrm{TiO}_{2}$ film with $\mathrm{HNO}_{3}$ showed an efficiency enhancement of about $250 \%$ whereas in Ref. [21], treating the DSSC sensitized with Glycyrrhiza glabra with $\mathrm{HCl}$ led to an efficiency enhancement of about $300 \%$ [21].

\section{TABLE II}

Photovoltaic parameters of the DSSCs with post-treatment of $\mathrm{TiO}_{2}$ electrode by the three acids.

\begin{tabular}{c|c|c|c|c|c|c}
\hline \hline $\begin{array}{c}\mathrm{TiO}_{2} \\
\text { post-treatment }\end{array}$ & $\begin{array}{c}J_{\mathrm{sc}} \\
{\left[\mathrm{mA} / \mathrm{cm}^{2}\right]}\end{array}$ & $\begin{array}{c}V_{\mathrm{oc}} \\
{[\mathrm{V}]}\end{array}$ & $\begin{array}{c}J_{\mathrm{m}} \\
{\left[\mathrm{mA} / \mathrm{cm}^{2}\right]}\end{array}$ & $\begin{array}{c}V_{\mathrm{m}} \\
{[\mathrm{V}]}\end{array}$ & $F F$ & $\begin{array}{c}\eta \\
{[\%]}\end{array}$ \\
\hline $\begin{array}{c}\mathrm{H} \text { HCl } \\
(0.1 \mathrm{M}, 5 \mathrm{~min})\end{array}$ & 0.87 & 0.56 & 0.68 & 0.47 & 0.65 & 0.31 \\
$\begin{array}{c}\mathrm{H}_{3} \mathrm{PO}_{4} \\
(0.1 \mathrm{M}, 5 \mathrm{~min})\end{array}$ & 1.15 & 0.52 & 0.80 & 0.39 & 0.54 & 0.32 \\
$\begin{array}{c}\mathrm{HNO}_{3} \\
(0.1 \mathrm{M}, 5 \mathrm{~min})\end{array}$ & 2.90 & 0.49 & 2.24 & 0.36 & 0.57 & 0.81
\end{tabular}




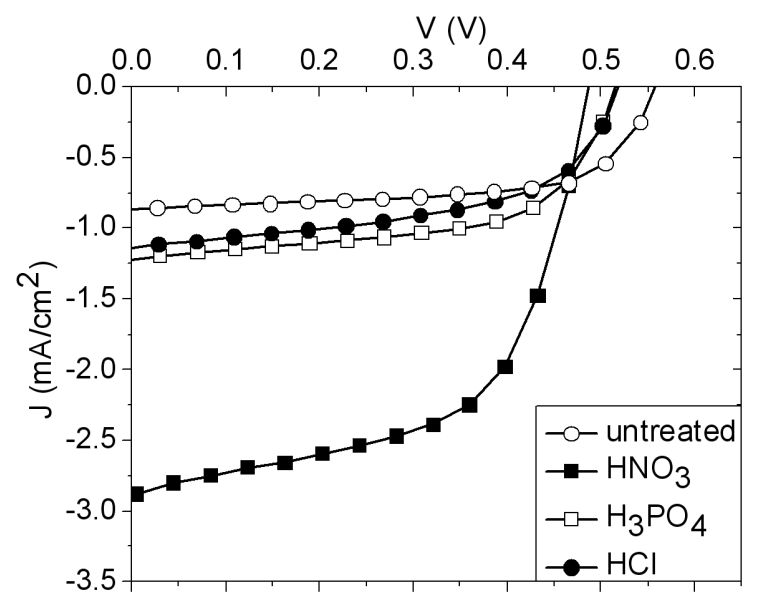

Fig. 3. Current density $(J)$ versus voltage $(V)$ characteristic curves of DSSCs with post-treatment of $\mathrm{TiO}_{2}$ electrode with the three acids.

\subsection{Electrochemical impedance spectroscopy}

Electrochemical impedance spectroscopy (EIS) is a useful method for the analysis of charge-transport processes and internal resistances [12]. The EIS measurements for the untreated DSSC were carried out in the dark and under an illumination of $100 \mathrm{~mW} / \mathrm{cm}^{2}$ at -0.4 , -0.6 , and $-0.8 \mathrm{~V}$. According to Fig. 4 which shows the Nyquist plots for these cells, there is a decrease in the impedances upon exposure to an illumination of $100 \mathrm{~mW} / \mathrm{cm}^{2}$. Equivalent circuit were obtained for the

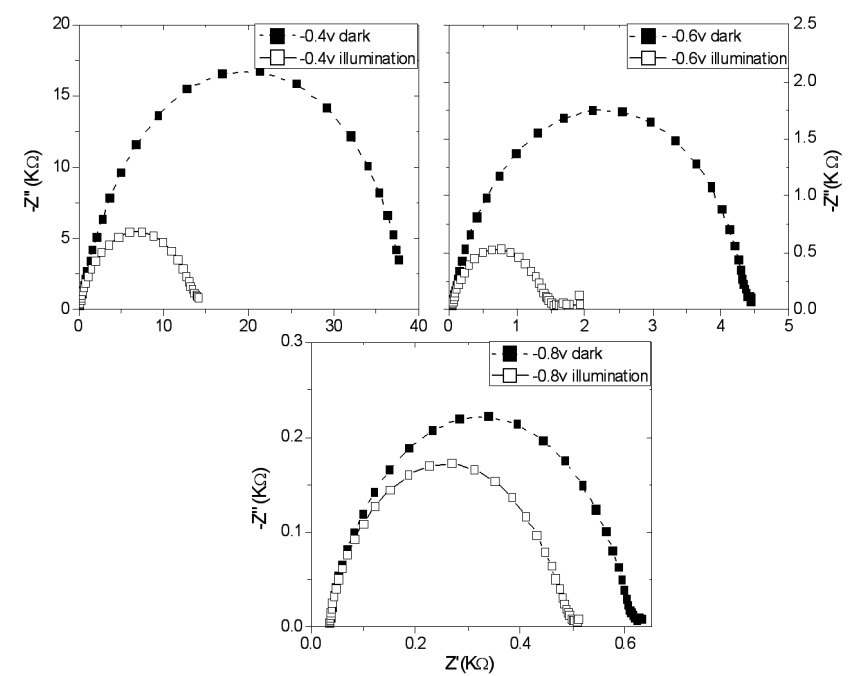

Fig. 4. Nyquist plots of the DSSC sensitized by purple carrot at $-0.4,-0.6$, and $-0.8 \mathrm{~V}$ in the dark and under an illumination of $100 \mathrm{~mW} / \mathrm{cm}^{2}$.

untreated DSSC in the dark and under an illumination of $100 \mathrm{~mW} / \mathrm{cm}^{2}$ at $-0.4,-0.6$, and $-0.8 \mathrm{~V}$ applied voltages as shown in Fig. 5. In Fig. $5, R_{\mathrm{S}}$ is the series resistance, CPE is the constant phase element, and $R_{\mathrm{CT}}$ is the charge-transfer resistance. Table III summarizes the equivalent circuit component values obtained from fitting the untreated DSSCs. It is clear that $R_{\mathrm{CT}} \gg R_{\mathrm{S}}$ which predicts fast electron transport and long lifetime of electrons in the film.

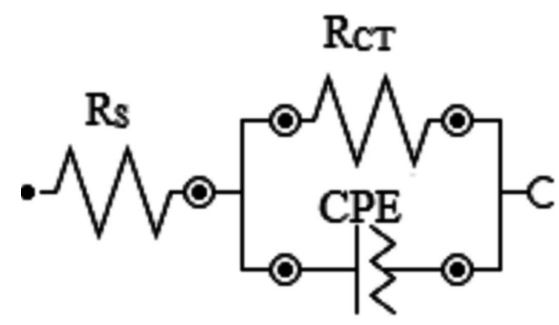

Fig. 5. The equivalent circuit for the DSSCs sensitized by purple carrot without any treatment.

TABLE III

EIS results from data-fitting of Nyquist plots to the equivalent circuit model.

\begin{tabular}{c|c|c|c}
\hline \hline Without treatment & $R_{\mathrm{S}}[\Omega]$ & $R_{\mathrm{CT}}[\mathrm{k} \Omega]$ & $C[\mu \mathrm{F}]$ \\
\hline -0.4 V dark & 34.70 & 40.90 & 3.16 \\
-0.4 V illumination & 34.20 & 13.90 & 2.79 \\
-0.6 V dark & 34.60 & 4.42 & 1.85 \\
-0.6 V illumination & 33.30 & 1.52 & 1.77 \\
-0.8 V dark & 34.20 & 0.59 & 1.28 \\
-0.8 V illumination & 33.70 & 0.48 & 1.29
\end{tabular}

\section{Conclusions}

Purple carrot was used as a sensitizer for DSSCs. This paper described the influence of pre- and posttreatments of the FTO glass substrate and the $\mathrm{TiO}_{2}$ film using hydrochloric $(\mathrm{HCl})$, phosphoric $\left(\mathrm{H}_{3} \mathrm{PO}_{4}\right)$, and nitric $\left(\mathrm{HNO}_{3}\right)$ acids. The pre-treatment of the FTO with phosphoric acid $\left(\mathrm{H}_{3} \mathrm{PO}_{4}\right)$ resulted in improved efficiencies of $130 \%$. The nitric acid $\left(\mathrm{HNO}_{3}\right)$ post-treated electrode showed an efficiency enhancement of about $250 \%$. These observations could be conferring to that the acid treatment contributed regular arrangement of the photoelectrode by the dispersion of $\mathrm{TiO}_{2}$ nanoparticles which provides much chemisorption site for the organic dyes. The improvement of $\mathrm{TiO}_{2}$ film electrical conductivity is achieved by enhancing the neck points between the nanoparticles, increasing dye loading and minimizing the recombination rate between the $\mathrm{TiO}_{2}$ film and the mediator.

\section{Acknowledgments}

The authors would like to express gratitude to the ministry of higher education for the financial support of this work.

\section{References}

[1] D. Chapin, C. Fuller, G. Pearson, J. Appl. Phys. 25, 676 (1954).

[2] B. O'Regan, M. Gratzel, Nature 353, 737 (1991). 
[3] K. Hara, T. Horiguchi, T. Kinoshita, K. Sayama, H. Sugihara, H. Arakawa, Solar En. Mater. Solar Cells 64, 115 (2000).

[4] N. Cherepy, G. Smestad, M. Graetzel, G. Zhang, J. Phys. Chem. B 101, 9342 (1997).

[5] W. Xu, S. Dai, L. Hu, Plasma Sci. Technol. 9, 556 (2007).

[6] F. Cao, G. Oskam, G.J. Meyer, P.C. Searson, J. Phys. Chem. 100, 17021 (1996).

[7] B. Kim, S.W. Park, J.Y. Kim, K. Yoo, J.A. Lee, M.W. Lee, D.K. Lee, J.Y. Kim, B. Kim, H. Kim, S. Han, H.J. Son, M.J. Ko, Am. Chem. Soc. Appl. Mater. Interfaces 5, 5201 (2013).

[8] C.C. Yang, H.Q. Zhang, Y.R. Zheng, Curr. Appl. Phys. 11, 147 (2011)

[9] S.A. Taya, T.M. El-Agez, K.S. ElRefi, M.S. AbdelLatif, Turk. J. Phys. 39, 24 (2015).
[10] M.S. Abdel-Latif, M.B. Abuiriban, T.M. El-Agez, S.A. Taya, Int. J. Renew. En. Res. 5, 294 (2015).

[11] G. Calogero, J. Yum, A. Sinopoli, G. Marco, M. Gratzel, M. Khaja, Solar Energy 86, 1563 (2012).

[12] M.R. Narayan, Renew. Sustain. En. Rev. 16, 208 (2012).

[13] K. Wongcharee, V. Meeyoo, S. Chavadej, Solar Energy Mater. Solar Cells 91, 566 (2007).

[14] H. Sancun, W. Jihuai, H. Yunfang, L. Jianming, Solar Energy 80, 209 (2006).

[15] Z. Wang, T. Yamaguchi, H. Sugihara, H. Arakawa, Langmuir 21, 4272 (2005)

[16] T. Watson, C. Charbonneau, D. Bryant, D. Worsley, Int. J. Photoen. 2012, 5183 (2012).

[17] M.S. Abdel-Latif, T.M. El-Agez, S.A. Taya, H.S. Ghamri, A.Y. Batniji, Int. J. Renew. En. Res. 5, 1034 (2015) 